\title{
PEMODELAN DIRECT QUADRATE (D-Q) PADA KENDALI KECEPATAN MOTOR INDUKSI TIGA PHASA DENGAN FIELD ORIENTED CONTROL (FOC) BERBASIS KENDALI P-I
}

\section{Direct Quadrate (D-Q) Modeling in the Speed Control System of Three Phase Induction Motors With Field Oriented Control (FOC) Based on P-I Controlled}

\author{
Rizana Fauzi ${ }^{1}$ dan Jumaddil Khair ${ }^{2}$ \\ ${ }^{1}$ Jurusan Teknologi Informasi, Fakultas Teknik, Universitas Tadulako \\ ${ }^{2}$ Program Studi Teknik Perawatan Mesin, Politeknik Industri Logam Morowali \\ e-mail: ${ }^{1}$ rfauzi86@gmail.com
}

Received 5 / 11 / 2018, Revised 15 / 11 / 2018, Accepted 26 / 11 / 2018

\begin{abstract}
The utilization of a 3 phase induction motor is increasingly developing, so research on speed regulation in 3 phase induction motors is also increasingly widely studied. This is because the use of 3 phase induction motors in industry and especially hybrid vehicles is increasingly being developed. But there are some disadvantages of induction motors, one of which is the characteristics of non-linear parameters, especially rotor resistance which has varying values for different operating conditions, so it cannot maintain its speed constantly if there is a change in load. This of course can affect the performance of an induction motor. To get a constant speed and better system performance on load changes a controller / controller is needed. This study aims to model direct-quadrate parameters (D-Q) using the Field Oriented Control (FOC) method based on Proportional-Integral (PI) controller. With the d-q parameter controlled, the induction motor will be more stable, because the $d-q$ parameter determines the stability of the change in torque and flux in the induction motor. Proportional-Integral (PI) control used is a classic control system that is easy because it does not need to look for a mathematical model of the system, but it remains effective because it has a fairly stable system response, by setting the best combination of proportional $(\mathrm{Kp})$ constants and Integrator constants ( Ki). In the results of the implementation, it can be seen that the use of FOC can be used as an approach in terms of setting the speed of the induction motor, and with the use of the PI control can help the output response get better with a shorter response time to reach the reference value.
\end{abstract}

keywords - System, Proportional-Integral, FOC, Induction motor

\section{Pendahuluan}

Motor induksi 3 fasa merupakan motor listrik yang sangat sering diaplikasikan khususnya pada dunia industri. Aplikasi motor induksi 3 phase semakin lama semakin berkembang, dikarenakan kehandalannya pada penggunaan di industri dan khususnya pada kendaraan hybrid semakin banyak dikembangkan. Diantara kelebihan motor induksi 3 phase juga terdapat beberapa kekurangan, salah satunya adalah karakteristik parameter yang tidak linier, terutama resistansi rotor yang memiliki nilai yang bervariasi untuk kondisi operasi yang berbeda, sehingga tidak dapat mempertahankan kecepatannya secara konstan bila terjadi perubahan beban. Dikarenakan hal tersebut, untuk mendapatkan kecepatan yang konstan dan respon sistem yang lebih baik terhadap perubahan beban maka dibutuhkan pengendali [1-3]. 


\section{Landasan Teori}

\subsection{Motor Induksi}

Pada prinsipnya motor Induksi 3 phase bekerja dengan memanfaatkan perbedaan fasa sumber untuk menimbulkan gaya putar pada rotornya [1]. Jika pada motor Induksi 1 phase untuk menghasilkan beda phase diperlukan penambahan komponen kapasitor, pada motor 3 phase perbedaan phase sudah didapat langsung dari sumber seperti terlihat pada gambar arus 3 phase berikut ini:

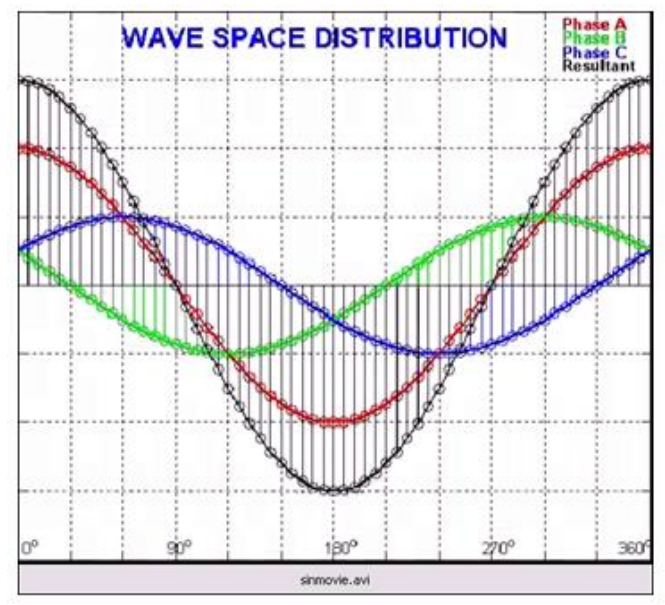

Gambar 1. Grafik arus 3 fasa [1][4]

Persamaan untuk pemodelan motor induksi, adalah sebagai berikut:

$$
\begin{gathered}
\overline{\mathrm{v}}_{\mathrm{s}}=\mathrm{R}_{\mathrm{s}} \overline{\mathrm{l}}_{\mathrm{s}}+\bar{\lambda}_{\mathrm{s}}+\mathrm{j} \omega_{\mathrm{e}} \bar{\lambda}_{\mathrm{s}} \\
\overline{0}=R_{r} \bar{l}_{r}+\bar{\lambda}_{r}+j\left(\omega_{e}-\omega_{r}\right) \bar{\lambda}_{r} \\
\bar{\lambda}_{s}=L_{s} \bar{l}_{i}+L_{m} \bar{\iota}_{r} \\
\bar{\lambda}_{r}=L_{m} \bar{l}_{s}+L_{r} \overline{\bar{l}}_{r} \\
T_{e}=3 \frac{P}{2} \frac{I_{r}^{2} r_{r}}{S w_{e}}
\end{gathered}
$$

Jika dipergunakan pengamatan konvensional, diperkirakan fluks stator dihitung berdasarkan persamaan motor menggunakan integrator murni sebagai berikut:

$$
\hat{\psi}_{s \alpha}=\int\left(u_{s \alpha}-i_{s \alpha} R_{s}\right) d t
$$


Diperkirakan fluks rotor dihitung dari perkiraan statorfluks sebagai berikut:

$$
\begin{gathered}
\widehat{\psi}_{\mathrm{r} \alpha}=-\left(\frac{\mathrm{L}_{\mathrm{s}} \mathrm{L}_{r}-\mathrm{L}_{\mathrm{m}}^{2}}{\mathrm{~L}_{\mathrm{m}}}\right) \mathrm{i}_{\mathrm{s} \alpha}+\frac{\mathrm{L}_{\mathrm{r}}}{\mathrm{L}_{\mathrm{m}}} \widehat{\psi}_{\mathrm{s} \alpha} \\
\widehat{\psi}_{r \beta}=-\left(\frac{L_{s} L_{r}-L_{m}^{2}}{L_{m}}\right) i_{s \beta}+\frac{L_{r}}{L_{m}} \widehat{\psi}_{s \beta}
\end{gathered}
$$

Perkiraan Sudut untuk fluks rotors diperoleh sebagai berikut.

$$
\begin{gathered}
\widehat{\omega}_{\mathrm{r}}=\frac{\mathrm{d} \widehat{\theta}_{\mathrm{r}}}{\mathrm{dt}} \text { where } \widehat{\theta}_{\mathrm{r}}=\tan ^{-1}\left(\frac{\widehat{\Psi}_{\mathrm{r} \beta}}{\widehat{\Psi}_{\mathrm{r} \alpha}}\right) \\
\widehat{\psi}_{s \beta}=\int\left(u_{s \beta}-i_{s \beta} R_{s}\right) d t
\end{gathered}
$$

Sehingga untuk mendapatkan kecepatan yang konstan dan peformansi motor yang lebih baik pada kecepatan rendah, dibutuhkan suatu metode pengontrolan yang mampu mengatasi setiap perubahan parameter pada motor induksi. Pada gambar di atas, arus 3 phase memiliki perbedaan phase 60 derajat antar phasenya. Dengan perbedaan ini, maka penambahan kapasitor tidak diperlukan. Konstruksi motor induksi secara detail terdiri atas dua bagian, yaitu : bagian stator dan bagian rotor. Stator adalah bagian motor yang diam, terdiri dari : badan motor, inti stator, belitan stator, bearing dan terminal box. Bagian rotor adalah bagian motor yang berputar, terdiri atas rotor sangkar dan poros rotor. Konstruksi motor induksi tidak memiliki komutator dan sikat arang. Ada dua jenis rotor pada motor induksi, yaitu jenis rotor sangkar tupai (squirrel -cage rotor) dan rotor belitan (wound-rotor). Kedua rotor ini mempunyai konstruksi stator dan prinsip kerja yang sama [2][3][5].

\section{Metode Penelitian}

\subsection{Field Oriented Control (FOC)}

Metode kendali kecepatan dengan Field Oriented Control (FOC) adalah suatu metode pengaturan medan pada motor AC, di mana dari sistem coupled diubah menjadi sistem decoupled. Dengan sistem ini arus penguatan dan arus beban motor dapat dikontrol secara terpisah, dengan demikian torsi dan fluksi juga dapat diatur secara terpisah, seperti halnya motor DC.

Pada FOC yang diatur adalah banyaknya fluks yang akan berdampak langsung dengan perubahan kecepatan pada motor induksi. Pengukuran besarnya fluks tidak diukur secara langsung, melainkan dapat diperkirakan dengan perubahan nilai dari kecepatan rotor motor yang dimonitor oleh sensor rotari. Kecepatan motor diumpan balikkan kemudian dibandingkan dengan kecepatan referensi oleh suatu komparator [6-7]. 


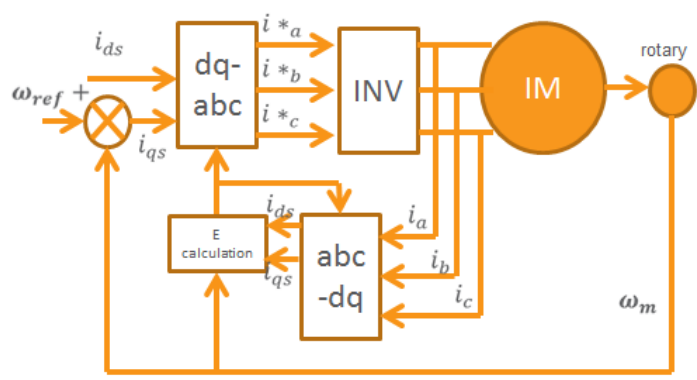

Gambar 2. diagram blok pengaturan kecepatan motor induksi dengan FOC[5][8][9]

Fluks rotor dan torsi dapat dikontrol secara terpisah oleh arus stator direct-axis (ids) dan arus quadratur-axis (iqs) secara berurutan. Besar arus quadratur-axis referensi (i*qs) dapat dihitung dengan torsi referensi $\mathrm{Te}^{*}$ menggunakan persamaan berikut,

$$
i_{q s}^{*}=\frac{2}{3} * \frac{2}{P} * \frac{L_{r}}{L_{m}} * \frac{T_{e}^{*}}{\lambda_{r}^{*}}
$$

dengan $\mathrm{Lr}$ adalah induktansi rotor, $\mathrm{Lm}$ adalah induktansi mutual, dan $\lambda \mathrm{r}$ adalah fluks linkage rotor estimasi, yang diperoleh dari persamaan berikut,

$$
\lambda_{r}=\frac{L_{m} i_{d s}}{1+\tau_{r} S}
$$

Dengan $\tau_{r}=\frac{L_{r}}{R_{r}}$ adalah konstanta waktu rotor. Besarnya arus direct-axis stator referensi $i_{q s}^{*}$ adalah tergantung dari input fluks referensi $\lambda_{r}^{*}$ yaitu,

$$
i_{d s}^{*}=\frac{\lambda^{*}}{L_{m}}
$$

Sudut flux rotor $\theta$ e untuk transformasi koordinat diperoleh dari perhitungan antara kecepatan putaran rotor $\omega \mathrm{m}$ dan kecepatan slip $\omega s l$, dengan persamaan,

$$
\theta_{e}=\int\left(\omega_{m}+\omega_{s l}\right) d t
$$

\section{Transformasi Clarke}

Transformasi Clarke atau yang juga sering disebut sebagai transformasi $\alpha \beta$ merupakan transformasi sistem tiga fasa $(a, b, c)$ menjadi sistem dua fasa $(\alpha, \beta)$ yang stasioner. Jika dianggap arus $a, b$, dan c bernilai sesuai dengan fungsi sinusoidal dan memiliki perbedaan fasa sebesar $120^{\circ}$ satu sama lainnya, maka arus tiga fasa tersebut dapat diubah ke dalam dua fasa yang diam, yaitu sumbu $\alpha-\beta$, atau sumbu $\alpha$ sebagai nilai real-nya, dan sumbu $\beta$ sebagai nilai imajinernya (kerangka referensi stator). Transformasi clarke dapat dilihat pada Gambar 3 berikut: 


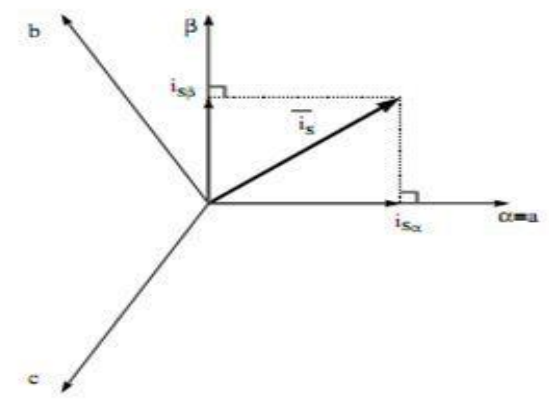

Gambar 3. Transformasi Clarke [9]

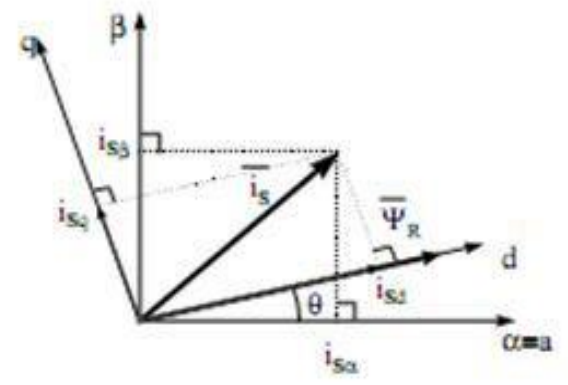

Gambar 4. Transformasi Clarke [9]

$\operatorname{Arus}_{s}$ pada Gambar 4. diatas bila dinyatakan sebagai fungsi dari komponen tiga fasa adalah sebagai berikut:

$$
\bar{l}_{s}^{s}=i_{s a} e^{j 0^{o}}+i_{s b} e^{j 120^{o}}+i_{s c} e^{j 240^{o}}
$$

dan dengan menggunakan identitas Euler $e^{j \omega t}=\cos (\omega t)+j \sin (\omega t)$ maka komponen $i_{s \alpha}$ dan $i_{s \beta}$ dari vector $\vec{l}_{s}^{s}$ (dengan super script $\mathrm{s}$ mengimplikasikan kerangka referensi stasioner/stator) dapat dinyatakan sebagai:

$$
\bar{l}_{s}^{s}=i_{s a}+j i_{s b}
$$

sehingga persamaan dalam bentuk matriks untuk mengubah komponen tiga fasa menjadi dua fasa, adalah sebagai berikut:

$$
\left[\begin{array}{l}
i_{\alpha} \\
i_{\beta}
\end{array}\right]=\sqrt{\frac{2}{3}}\left[\begin{array}{ccc}
1 & -\frac{1}{2} & -\frac{1}{2} \\
0 & \frac{1}{2} \sqrt{3} & -\frac{1}{2} \sqrt{3}
\end{array}\right]\left[\begin{array}{l}
i_{a} \\
i_{b} \\
i_{c}
\end{array}\right]
$$

dengan konstanta $\sqrt{\frac{2}{3}}$ yang menunjukkan sistem power invariant. 
Transformasi Park merupakan transformasi sistem dua fasa stasioner, $\alpha$ dan $\beta$, menjadi sistem dua fasa yang berputar, direct (d) dan quadrature (q) atau seringkali disebut transformasi dq. Dari gambar $8 \mathrm{~b}$ diatas, hubungan antara vector $\bar{\imath}_{s}^{s}$ pada kerangka referensi stasioner dan vector $\bar{l}_{s}^{e}$ pada kerangka referensi yang bergerak adalah:

$$
\bar{l}_{s}^{e}=\bar{\imath}_{s}^{s} e^{-j \theta}
$$

persamaan di atas dapat dijabarkan menjadi:

$$
\begin{gathered}
i_{s d}=j i_{s q}=\left(i_{s \alpha}+j i_{\beta}\right)[\cos (-\theta)+j \sin (-\theta] \\
{\left[\begin{array}{l}
i_{s d} \\
i_{s q}
\end{array}\right]=\left[\begin{array}{cc}
\cos \theta & \sin \theta \\
-\sin \theta & \cos \theta
\end{array}\right]\left[\begin{array}{l}
i_{s \alpha} \\
i_{s \beta}
\end{array}\right]}
\end{gathered}
$$

atau bila persamaan di atas dinyatakan dalam matriks, maka:

Transformasi Clarke di dalam field oriented control motor induksi digunakan untuk mentransformasikan arus stator tiga fasa $\left(\mathrm{i}_{\mathrm{a}}, \mathrm{i}_{\mathrm{b}}\right.$, dan $\mathrm{i}_{\mathrm{c}}$ ) pada bidang stasioner (stationary reference frame) ke arus stator ortogonal dua fasa $\left(\mathrm{i}_{\alpha}\right.$ dan $\mathrm{i}_{\beta}$ ) pada bidang ortogonal (orthogonal reference frame). Sedangkan Transformasi Park digunakan untuk mentransformasikan arus stator $\left(\mathrm{i}_{\alpha}\right.$ dan $\left.\mathrm{i}_{\beta}\right) \mathrm{ke}$ arus stator dua fasa ( $\mathrm{i}_{\mathrm{ds}} \mathrm{dan}_{\mathrm{iqs}}$ ) pada bidang putar (rotating reference frame).

\section{Kendali Proporsional-Integral (P-I)}

Sistem kontrol PI terdiri dari dua buah cara pengaturan yaitu kontrol P (Proportional) dan I (Integral), dengan masing-masing memiliki kelebihan dan kekurangan[2]. Dalam perancangan sistem kontrol PI yang perlu dilakukan adalah mengatur parameter P dan I agar tanggapan sinyal keluaran system terhadap masukan tertentu sebagaimana yang diinginkan [4].

\section{Kendali Proporsional}

Kontrol P jika G(s) = kp, dengan $\mathrm{k}$ adalah konstanta. Jika $\mathrm{u}=\mathrm{G}(\mathrm{s}) \cdot \mathrm{e}$ maka $\mathrm{u}=\mathrm{Kp} \cdot \mathrm{e}$ dengan $\mathrm{Kp}$ adalah Konstanta Proporsional [6]. Kp berlaku sebagai Gain (penguat) saja tanpa memberikan efek dinamik kepada kinerja kontroler. Penggunaan kontrol P memiliki berbagai keterbatasan karena sifat kontrol yang tidak dinamik ini. Walaupun demikian dalam aplikasi-aplikasi dasar yang sederhana kontrol $\mathrm{P}$ ini cukup mampu untuk memperbaiki respon transien khususnya rise time dan settling time.

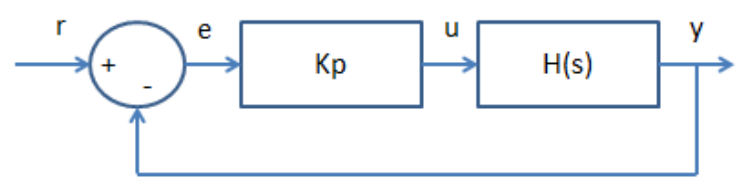

Gambar 5. a.Kendali P, b.Kendali I 


\section{Kendali Integratif}

Jika G(s) adalah kontrol I maka u dapat dinyatakan sebagai $u(t)=[$ integrale $(t) d T] K i$ dengan Ki adalah konstanta Integral, dan dari persamaan diatas, $\mathrm{G}(\mathrm{s})$ dapat dinyatakan sebagai $u=K d$. [deltae / deltat] Jika $\mathrm{e}(\mathrm{T})$ mendekati konstan (bukan nol) maka u(t) akan menjadi sangat besar sehingga diharapkan dapat memperbaiki error. Jika e(T) mendekati nol maka efek kontrol I ini semakin kecil. Kontrol I dapat memperbaiki sekaligus menghilangkan respon steady-state, namun pemilihan Ki yang tidak tepat dapat menyebabkan respon transien yang tinggi sehingga dapat menyebabkan ketidakstabilan sistem.

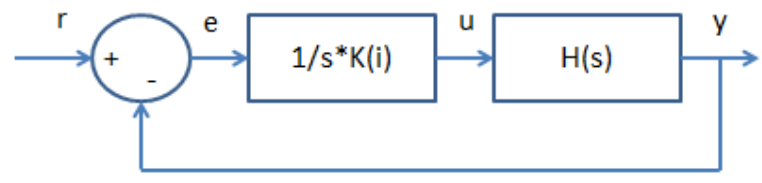

Gambar 6. Kendali I

\section{Desain Sistem}

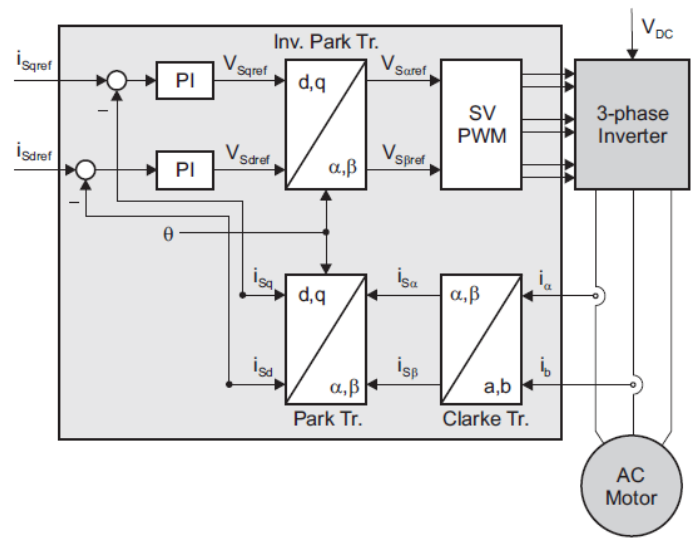

Gambar 7. Blok Desain Sistem

Table 1. parameter of induction motor

\begin{tabular}{|l|l|l|}
\hline No. & Parameter & value \\
\hline 1. & Nominal power & $3730 \mathrm{VA}$ \\
\hline 2. & Voltage line-line & $460 \mathrm{~V}$ \\
\hline 3. & Frequency & $60 \mathrm{~Hz}$ \\
\hline 4. & Rotor resistance & $0.816 \mathrm{ohm}$ \\
\hline 5. & Mutual inductance & $69.31 \mathrm{e}-3 \mathrm{H}$ \\
\hline
\end{tabular}


Pada bagan di atas, dapat kita lihat bahwa arus stator direct-axis $\left(i_{d s}^{*}\right)$ yang digunakan untuk penguatan flux dibuat konstan yang kemudian dijadikan parameter untuk IFOC dan pembanding konstan pada slip [6]. Kecepatan putar rotor aktual secara kontinu dibaca oleh sensor kecepatan yang kemudian dibandingkan dengan kecepatan rotor referensi. Nilai selisih antara kecepatan rotor aktual dan referensi kemudian dijadikan sebagai nilai error yang akan diolah oleh kendali PI yang keluarannya berupa nilai arus quadratur-axis $\left(i_{q s}^{*}\right)$. Arus stator direct-axis $\left(i_{d s}^{*}\right)$ dan nilai arus quadratur-axis $\left(i_{q s}^{*}\right)$ dengan metode IFOC ditransformasi menjadi arus sefasastasioner referensi $\left(i_{a s}^{*}, i_{b s}^{*}, i_{c s}^{*}\right)$ yang diolah oleh PWM inverter menjadi arus 3 phase untuk menggerakkan motor induksi 3 phase[8].

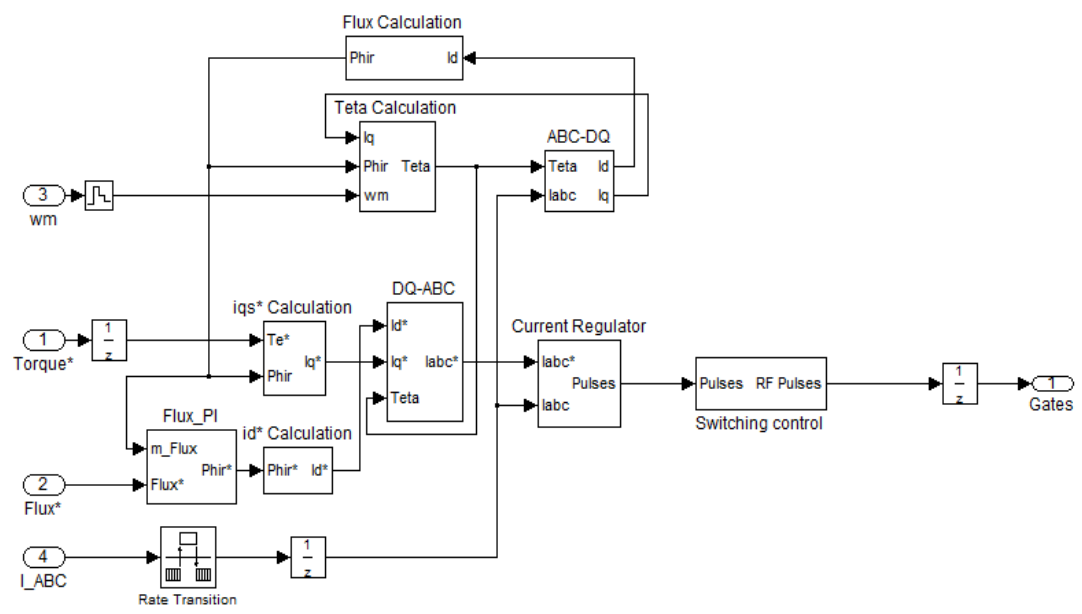

Gambar 8. Blok proses FOC

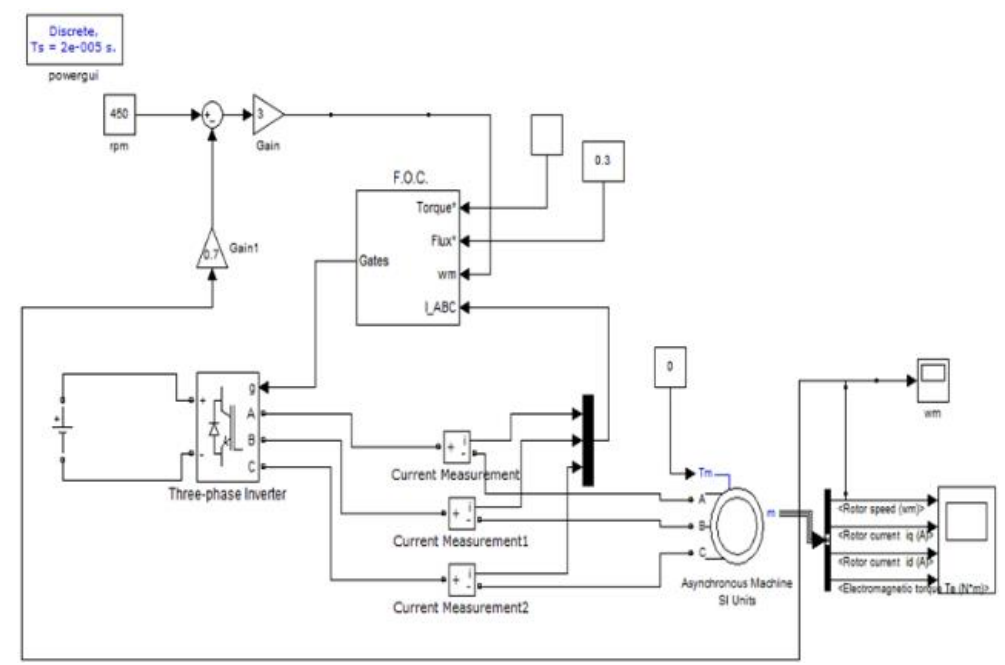

Gambar 9. Kendali motor induksi yang hanya menggunakan FOC 


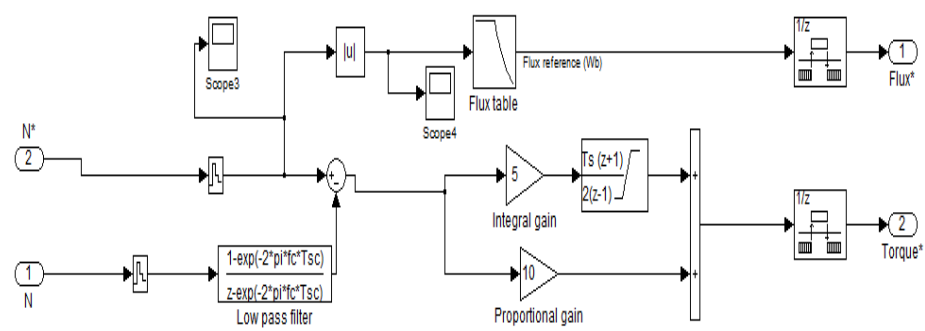

Gambar 10. Kendali kecepatan dengan Kendali PI

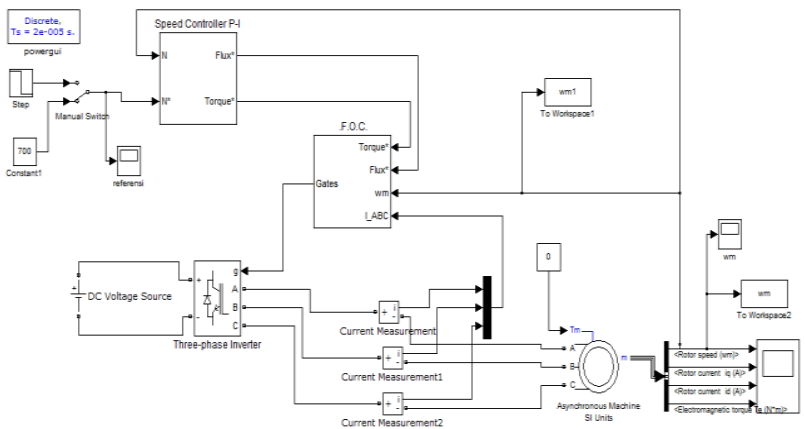

Gambar 11. FOC dengan menggunakan kendali kecepatan PI pada motor induksi

\section{Pembahasan Dan Hasil}

\subsection{Implementasi Sistem}

Pada grafik gambar 12, dapat kita lihat pada nilai referensi 700rpm, nilai arus penguatan torsi sangat tidak stabil mulai dari sistem mulai berjalan hingga mencapai nilai referensi. Saat mencapai nilai referensi perubahan nilai arus penguatan torsi masih tidak stabil. Untuk arus penguatan medan dapat dilihat bahwa perubahan yang terjadi tidak stabil mulai dari start hingga mencapai nilai referensi. Hal ini berimplikasi langsung pada ketidakstabilan kecepatan rotor mulai dari start hingga mencapai nilai referensi 700rpm.

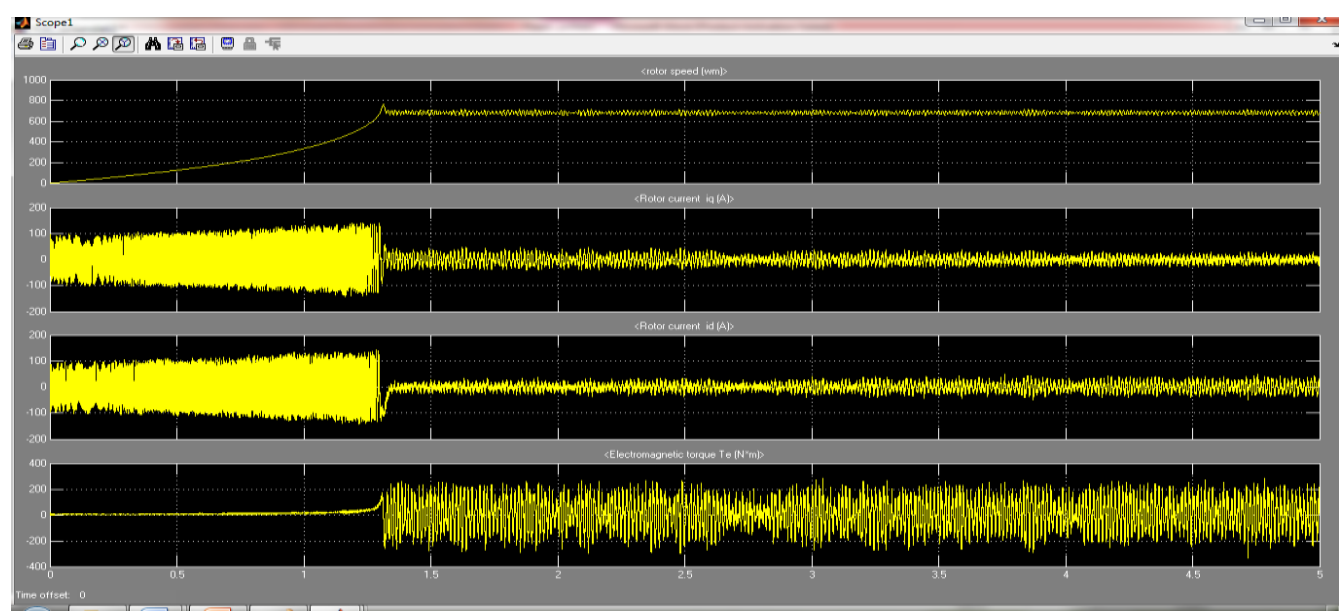

Gambar 12. Grafik output perubahan kecepatan dengan acuan perubahan parameter d-q (parameter arus torsi dan arus medan) 


\subsection{Dengan metode FOC berbasis kendali kecepatan P-I}

\subsubsection{Dengan kecepatan referensi 700rpm}

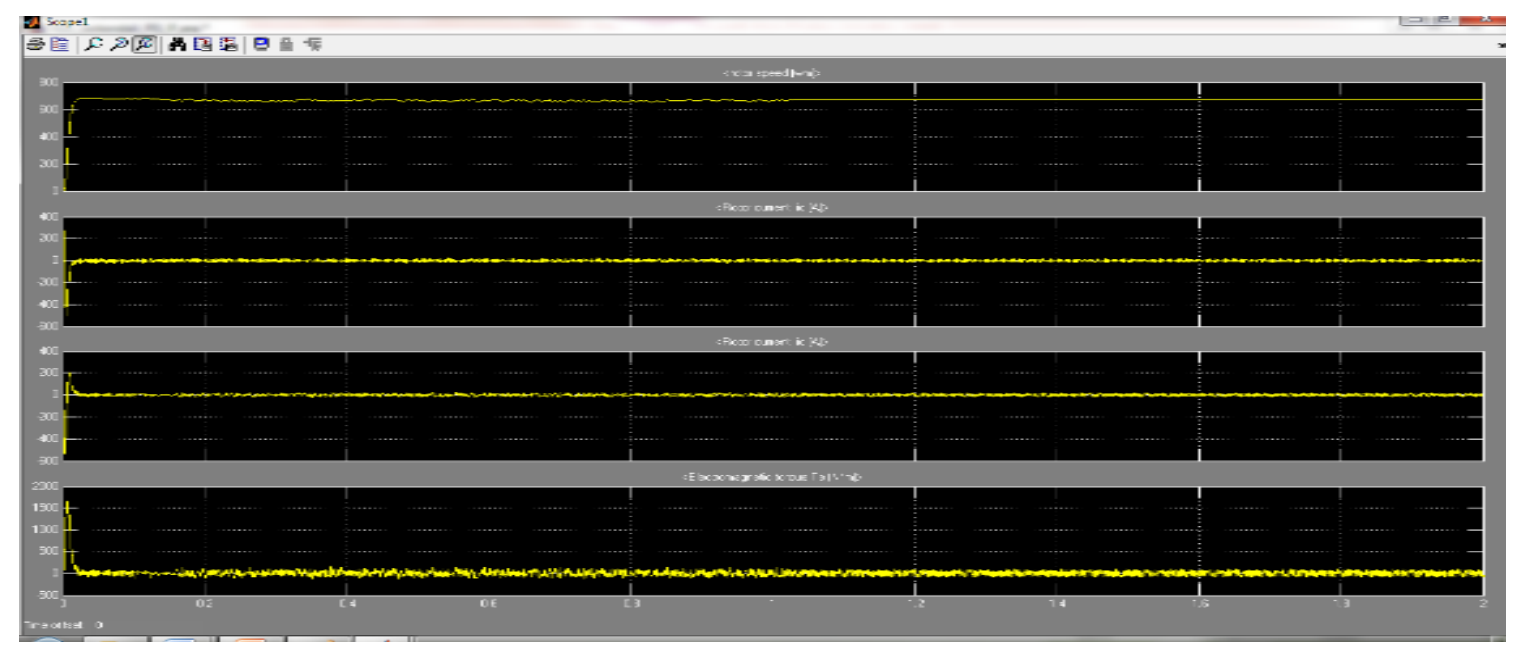

Gambar 13. Grafik output perubahan kecepatan dengan acuan perubahan parameter d-q (parameter arus torsi dan arus medan dengan pengendali P-I)

Pada gambar 13 terlihat bahwa nilai perubahan penguatan arus torsi cukup stabil. Dan penguatan arus medan juga mengalami perubahan yang cukup stabil. Hal ini tentu saja mempengaruhi respon kecepatan, yang dapat dilihat pada grafik rotor speed. Sistem mencapai nilai referensi sebesar 800rpm dalam waktu 0,05 detik. Hal ini mengakibatkan respon sistem sangat cepat dari awal start hingga mencapai nilai referensi. Saat mencapai nilai referensi. Sistem tidak mengalami overshoot sebesar, dan saat mencapai nilai referensi, sistem tidak berosilasi.

\subsubsection{Dengan kecepatan referensi 800rpm}

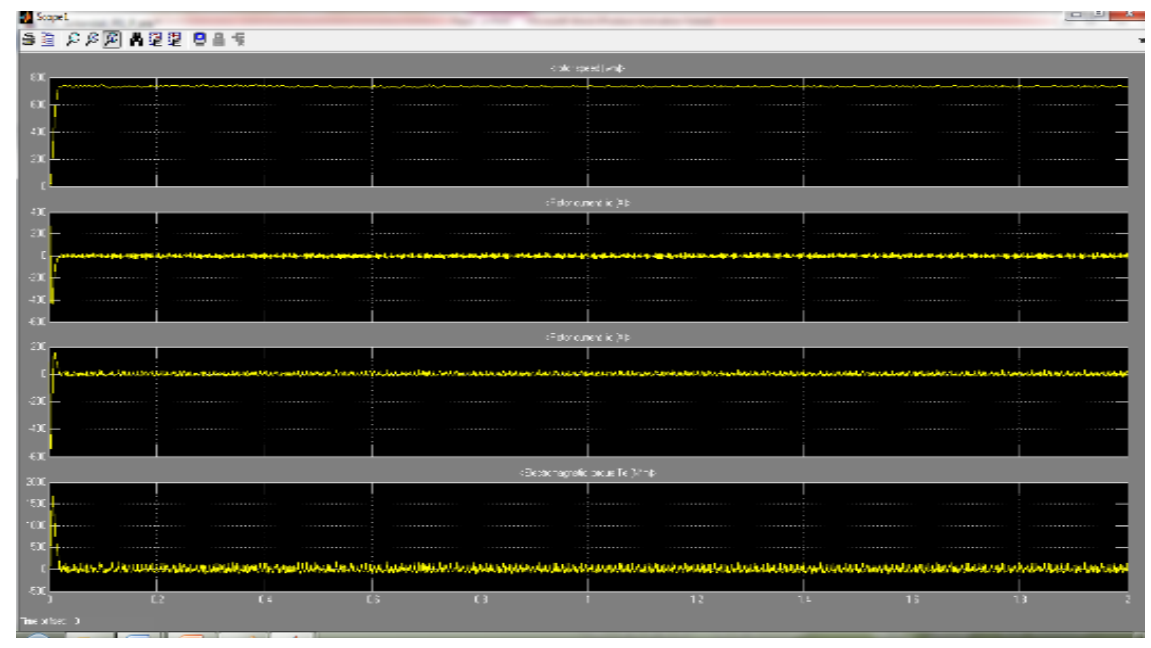

Gambar 14. Grafik output perubahan kecepatan dengan acuan perubahan parameter d-q (parameter arus torsi dan arus medan dengan pengendali P-I)

Pada grafik gambar 14, dapat kita lihat pada nilai referensi 700rpm, nilai arus penguatan torsi sangat stabil mulai dari sistem mulai berjalan hingga mencapai nilai referensi. Saat mencapai nilai 
referensi perubahan nilai arus penguatan torsi masih cukup stabil. Untuk arus penguatan medan dapat dilihat bahwa perubahan yang terjadi cukup stabil mulai dari start hingga mencapai nilai referensi. Hal ini berimplikasi langsung pada kestabilan kecepatan rotor mulai dari start hingga mencapai nilai referensi 700rpm. Respon sistem juga meningkat dengan time respon 0,05 detik.

\section{Kesimpulan}

Dari hasil penelitian yang telah dilakukan oleh peneliti, maka dapat disimpulkan beberapa hal sebagai berikut:

1. Dalam kendali kecepatan motor induksi penggunaan metode kendali medan (FOC) saja belum mampu manghasilkan performa yang baik, sehingga diperlukan adanya kendali kecepatan yang dapat memberikan tanggapan respon input yang baik, sehingga menghasilkan keluaran yang baik dengan nilai osilasi yang sangat kecil dan respon yang cepat.

2. Penggunaan kendali PI sebagai speed controller sangat baik digunakan dikarenakan dengan adanya kendali PI, nilai eror overshot dan undershot dapat diminimalisir sehingga pencapaian referensi dapat dilakukan dengan cepat dan dengan tingkat error yang relatif lebih kecil.

\section{DAFTAR REFERENSI}

[1] N. Mutoh, S. Kaneko, T. Miyazaki, R. Masaki, dan S. Obara, "A torque controller suitable for electric vehicles," IEEE Transactions On Industrial Electronics, vol. 44, no. 1, hlm. 54-63, (1997).

[2] S. Peresada, A. Tonielli, dan R. Morici, "High-performance indirect field-oriented outputfeedback control of induction motors," Automatica, vol. 35, no. 6, hlm. 1033-1047, (1999).

[3] J.-S. Yu, S.-H. Kim, B.-K. Lee, C.-Y. Won, dan J. Hur, "Fuzzy-logic-based vector control scheme for permanent-magnet synchronous motors in elevator drive applications," IEEE transactions on Industrial Electronics, vol. 54, no. 4, hlm. 2190-2200, (2007).

[4] J. Rodriguez, J. Pontt, C. Silva, R. Huerta, dan H. Miranda, "Simple direct torque control of induction machine using space vector modulation," Electronics Letters, vol. 40, no. 7, hlm. 412-413, (2004).

[5] D.-C. Lee, S.-K. Sul, dan M.-H. Park, "High performance current regulator for a field-oriented controlled induction motor drive," IEEE Transactions on Industry Applications, vol. 30, no. 5, hlm. 1247-1257, (1994).

[6] M. Vasudevan, R. Arumugam, dan S. Paramasivam, "High-performance adaptive intelligent direct torque control schemes for induction motor drives," Serbian Journal of Electrical Engineering, vol. 2, no. 1, hlm. 93-116, (2005).

[7] S. Dam, A. Saha, P. K. Saha, dan G. K. Panda, "PID controller based closed loop control of Lmatrix based induction motor using V/f constant method," Journal of Scientific Theory and Methods, hlm. 1-21, (2012).

[8] A. Kusagur, S. F. Kodad, dan B. S. Ram, "Modelling of induction motor \& control of speed using hybrid controller technology," Proc. Int. Journal of Theoretical Information \& Technology (JATIT), vol. 10, no. 2, hlm. 117-126, (2009).

[9] C. C. Chan dan K. T. Chau, "An overview of power electronics in electric vehicles," IEEE transactions on Industrial Electronics, vol. 44, no. 1, hlm. 3-13, (1997). 